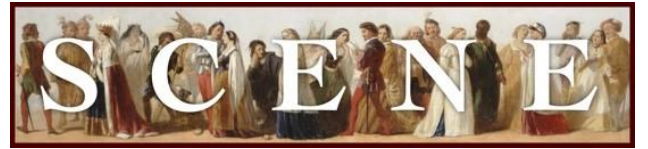

\title{
Stratford's Breath of Kings Offers Bold and Bumpy Rebellion
}

by Jim Volz. Written on 2016-08-23. Published in 2017 Issue 1.

For the production: Breath of Kings: Rebellion (2016, Stratford Festival of Canada, Canada). See production details at the end of the review.

IT TAKES INTREPID SHAKESPEARE FANATICS TO ENDURE AND APPRECIATE THE BOMBAST of Richard the Second, Henry the Fourth, Part 1, Henry the Fourth, Part 2, and Henry the Fifth all in one day, but that was the challenge for Stratford Theater attendees who watched the Graham Abbey conceived and adapted Breath of Kings: Rebellion $\&$ Redemption this summer. Audiences could have chosen to break them into their two separate parts (Rebellion $\&$ Redemption), but to fully appreciate the diverse repertory company, it was best to summon up the swagger and bravado of Shakespeare's best soldiers and plunge right in.

As seasoned theatergoers know, the play is a bumpy rollercoaster ride with the long-winded grandiloquence of Richard the Second slowing Bolingbroke's eventual drive to the throne. It's actually a pretty simple story of political missteps with Richard the Second's underestimation of Bolingbroke, allowing ego and advisors to mistakenly send the future Henry the Fourth (Bolingbroke) into exile. Bolingbroke's complicity in the king's murder was the second major misstep, both in terms of reconciling his own guilt and his countrymen's loyalties and ambitions.

As both adaptor and lead actor (Bolingbroke/Henry the Fourth), one can't help but suspect that the incisive cutting and trimming Abbey achieved in bringing the four plays in under six hours ran into significant snags when paring down his own character's bluster. Mr. Abbey offered up an interesting and forceful Henry the Fourth but the external posturing and pontification often detracted from the audience's understanding of the usurper's motivations, inner struggles, and tortured soul.

Tom Rooney as Richard the Second delivered a more nuanced, assertively suppliant, forcibly departing king who understood both the power and burdens of the hollow crown. The glory of the Stratford Festival, of course, remained in its ability to tell a story with clarity, cleverness, 
and panache, and transforming the Tom Patterson Theater into an arena with the audience stacked on top of the playing fields, the battle fields, and courts kept most theater members engaged. Anahita Dehbonehie's set design shrewdly converted the stage from a dirt battle field (actually something similar to tire shreds to keep the dust down) to the court with the help of a few brooms, rakes, and shovels. Yannik Larivée's costume design was inventive and helpful in determining who was who, and composer and Sound Designer Debashis Sinha underscored the intermittent action with a strong guiding hand without tromping on the language.

In Part 2 of Rebellion, Geraint Wyn Davies's Falstaff was as savvy as he was salacious, and lead us through Henry the Fourth, Part 1 with gusto and intelligence. Johnathan Sousa as Henry Percy/Hotspur was a feisty, fur-covered, single-minded warrior with enough humanity that one felt sorry for the treachery that lead to his ill-fated demise. Araya Mengesha as Prince Hal survived a slow start where he was gobbled up in scenes with more seasoned actors.

Fortunately, he hit his stride midway and despite some seeming vocal strain or limits, stayed focused and carried the day. His best scenes were with the infinitely likable Davies as Falstaff, and together, they brought Rebellion and the trimmed Henry the Fourth, Part 1 to a satisfying conclusion.

Kate Hennig as Mistress Quickly made understatedly bold choices and clearly ran the Boar's Head. Michelle Giroux as Doll Tearsheet captured the pathetic hell-bent-on-survival heart of the character, and Stephen Russell as the Earl of Westmoreland was solid from start to finish. Nigel Shawn Williams also excelled as the Earl of Northumberland, and of course there are too many other fine performances to mention.

Directors Weyni Mengesha and Mitchell Cushman carefully blended the sights, sounds, speeches, and choreography of the two plays with experienced eyes and a clear vision. The heart of the history played center on the kings (and men who would be king), but the rapid pulse of each scene was accomplished by the parade of actors who played the dukes, duchesses, bishops, earls, and queens. The Stratford Festival was blessed by the depth of its overall company, and the artistic team was cast well with a strong and surprisingly liberal colour and gender conscious approach with women in men's roles and mixed-race families that adroitly allowed the words and talent to carry the day.

Jim Volz is an international arts consultant, author, producer, and professor based in Orange County at California State University, Fullerton. He served as a longtime critic/arts columnist for New York's Back Stage and founding editor of the Shakespeare Theatre Association's international magazine, Quarto. He has produced over 100 professional productions, consulted for over 100 arts institutions and published more than 100 articles on management, arts criticism, Shakespeare, and theatre in American Theatre, Oxford University Press's Theatre Research International, Hollywood's Drama-Logue and myriad other 
articles for national and international publications. He is a Ph.D. graduate from the University of Colorado,Boulder.jvolz@fullerton.edu

\section{Production Details}

\section{General}

Title

Breath of Kings: Rebellion

Year 2016

Theater Company

Stratford Festival of Canada

Theaters

Tom Patterson Theatre (Canada)

Start Date

2016-06-22

End Date

2016-09-24

\section{Cast}

\begin{tabular}{|c|}
\hline KING HENRY IV \\
\hline KING RICHARD THE SECOND \\
\hline PRINCE HAL \\
\hline JOHN OF GAUNT \\
\hline PRINCE JOHN OF LANCASTER \\
\hline DUKE OF YORK \\
\hline BOLINGBROOK \\
\hline EARL WESTMORELAND \\
\hline AUMERLE \\
\hline BLUNT \\
\hline EARL OF WORCESTER \\
\hline THOMAS MOWBRAY \\
\hline EARL OF SALISBURY \\
\hline HOTSPUR \\
\hline SIR JOHN Bushy \\
\hline ARCHBISHOP OF YORK \\
\hline SiR William BAGot \\
\hline SIR HENRY GREEN \\
\hline EARL OF DOUGLAS \\
\hline EARL OF NORTHUMBERLAND \\
\hline SIR RICHARD VERNON \\
\hline SiR JOHN FALSTAFF \\
\hline NED POINS \\
\hline BISHOP OF CARLISLE \\
\hline
\end{tabular}

Scene. University of Victoria. 2017 Issue 1

\author{
Graham Abbey \\ TOM ROONEY \\ Araya Mengesha \\ STEPHEN RUSSELL \\ SEBASTIEN HEINS \\ RANDY HUGHSON \\ GRAHAM ABBEY \\ STEPHEN RUSSELL \\ Sebastien Heins \\ IRENE POOLE \\ WAYNE BEST \\ CARLY STREET \\ Mikaela Davies \\ JOHNATHAN SOUSA \\ ANUSREE ROY \\ CARLY STREET \\ SHANE CARTY \\ GoRdon S. MILLER \\ CARLY STREET \\ NigEL SHAWN Williams \\ SHANE CARTY \\ GERAINT WYN DAVIES \\ GORDON S. MILLER \\ Kate HeNNig
}




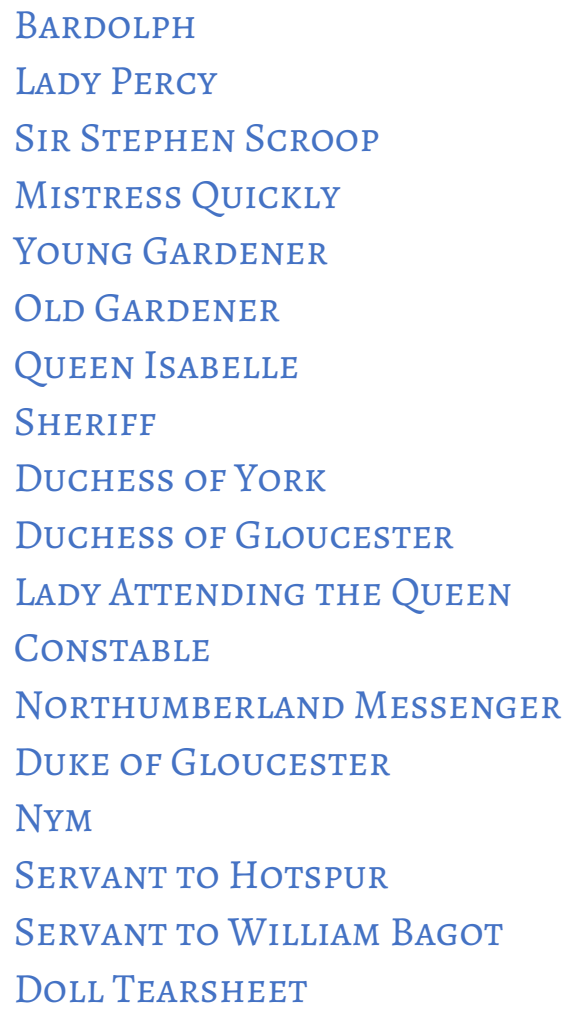

\section{Creatives}

DIRECTOR

ASSISTANT DiRECTOR

Costume Designer

Set Designer

LIGHTING DESIGNER

SOUND DESIGNER

COMPOSER

Fight DiRECTOR

Stage Manager

Production Stage Manager

Production Stage Manager

Associate Director

CONCEIVER

ADAPTOR

Assistant Stage Manager

Assistant Lighting Designer
Nigel ShaWn Williams

CARLY STREET

IRENE POOLE

Kate HeNNig

CARLY STREET

GERAINT Wyn DAVIES

MiCHELLE GIROUX

IRENE POOLE

ANUSREE ROY

Kate HeNNig

Mikaela Davies

RANDY HUGHSON

Michelle GiROUX

WAYNE BEST

SHANE CARTY

Mikaela Davies

Mikaela Davies

MICHELLE GIROUX
Mitchell Cushman

Weyni Mengesha

BRONWYN STEINBERG

YANNIK LARIVEE

Anahita Dehbonehie

Kimberly PURTEll

DEBASHIS SINHA

DEBASHIS SINHA

JOHN STEAD

MAXWELL T. WILSON

JUDY FARTHING

JANINE RALPH

GRAHAM ABBEY

GRAHAM ABBEY

GRAHAM ABBEY

KATHERINE ARCUS

C.J. Astronomo 


$\begin{array}{ll}\text { Assistant Costume Designer } & \text { Francesca Callow } \\ \text { Assistant Costume Designer } & \text { Caitlin Luxford } \\ \text { Apprentice Stage Manager } & \text { Gregory McLaughlin } \\ \text { Associate Fight Director } & \text { Geoff Scovell } \\ \text { Assistant Stage Manager } & \text { Zeph Williams }\end{array}$

